DIGITAL COMMONS
@ UNIVERSITY OF SOUTH FLORIDA

Volume 2

Issue 1 Volume 2.1 (Spring 2012): Open Access

\section{ABO: Interactive Journal for Women in the Arts, 1640-1830}

Article 3

2012

\title{
At The Precipice of Community: Feral Openness and the Work of Mary Robinson
}

Anne Milne

University of Guelph, anne.milne@utoronto.ca

Follow this and additional works at: https://digitalcommons.usf.edu/abo

Part of the Dramatic Literature, Criticism and Theory Commons, Educational Methods Commons, Feminist, Gender, and Sexuality Studies Commons, and the Literature in English, British Isles Commons

\section{Recommended Citation}

Milne, Anne (2012) "At The Precipice of Community: Feral Openness and the Work of Mary Robinson," ABO: Interactive Journal for Women in the Arts, 1640-1830: Vol.2: Iss.1, Article 3.

http://dx.doi.org/10.5038/2157-7129.2.1.2

Available at: https://digitalcommons.usf.edu/abo/vol2/iss1/3

This Scholarship is brought to you for free and open access by Digital Commons @ University of South Florida. It has been accepted for inclusion in ABO: Interactive Journal for Women in the Arts, 1640-1830 by an authorized administrator of Digital Commons @ University of South Florida. For more information, please contact digitalcommons@usf.edu. 


\section{At The Precipice of Community: Feral Openness and the Work of Mary Robinson}

\section{Keywords}

ecocriticism, Mary Robinson, thing theory

Creative Commons License

(c) (i) $\odot$

This work is licensed under a Creative Commons Attribution-No Derivative Works 3.0 License. 
In this paper I cast Mary Darby Robinson (1758-1800) as a feral figure and suggest that a consideration of the feral is central to an understanding of both her life and work. Here I look briefly at Robinson's 1801 Memoirs and their Continuation (thought to have been compiled/written by Robinson's daughter Maria Elizabeth and Robinson’s friend, Samuel Jackson Pratt) ${ }^{1}$ and two of her poems about wildness, madness and marginality, "The Maniac" from Robinson's 1793 Poems, written overnight under the influence of eighty drops of laudanum and "The Savage of Aveyron," Robinson's response to the sensational news story of the capture of a feral boy in south-central France in 1799 from her 1806 Poetical Works. I locate Robinson's ferality first in what I call her 'thingness' and later in her 'difference' - her identity after 1783 as a physically disabled woman addicted to opiates (which she used to manage pain). Incorporating the feral as a rich unaccountability between domesticated and wild into a reading of these texts necessitates a rethinking of Robinson's relationship to and in her world and our world. As a conceptual framework, the feral also offers a potential for new assessments of the roles feminist literary critics play in the post-recovery milieu of twenty-first century feminism.

Developing an enlarged and more multifaceted understanding of the term feral is part of reading new life into critical interpretations of Robinson's work. As a term, feral is generally used in the twentieth and twenty-first centuries to describe an animal or plant which has "lapsed into a wild [condition] from a domesticated condition” but the word also has seventeenth-century associations with the "brutal, savage," and "uncultivated" (adj.2, def. 1 and 2) as well as to "a deadly nature," the "funereal," the "fatal," and gloominess (adj.1, def. 1a and 2). The feral is generally read as a negative descriptor, an uncomfortable state between the more accepted wild and domesticated states. Yet the feral is more dynamic than this and suggests, even in its negative connotations and associations with risk, a position that I have suggested elsewhere "supports and embodies processes that engender multiplicities and lateral flows in perspectives and perceptions” (Milne 331) and, as cultural studies critic Nicholas Garside suggests, democratizes by creating “discursive moments” that can reorient communities (Garside 64-5).

Feral is an ephemeral term that has, on the one hand, not served its inhabitants well and yet also has close positive associations with powerful spaces, identities and practices such as borderlands, margins, thresholds, hybrids, becomings, standpoints, situated knowing, nomadism, etcetera. That the feral exists and thrives on its unaccountability aligns it also with critiques of traditional Western epistemologies such as Walter Mignolo’s postcolonial reconceptualization of knowledge that works to "reinscribe . . . the 'colonial difference' into the order of representation" (Alcoff 87; see also Milne 342 n.13). This is accomplished through a "double critique" that makes use of "a more inclusive concept of knowledge that incorporates both doxa [opinion or mere belief] and episteme [justified belief] ... " (Alcoff 95, italics mine). I would add "and ways of knowing” to Alcoff's description since Mignolo also puts great emphasis on knowledges that do not or cannot utilize language (Mignolo 9).

In a literary critical context, I am uncertain if feral encompasses what ecocritic Timothy Morton describes as non-identity or ambience, but certainly like the forces Morton describes, the feral worries "corners and edges [ . . and] make[s] it hard to maintain a solid center" and legitimizes itself in the role of the stranger "who wander[s] into and out of the world, constituting it as its 
boundaries, but also undermining its coherence” (Morton 81). Morton's work is helpful for reading Robinson, but I also situate Robinson's work within feminism. I wonder, for example, if Robinson and these specific works can be read through feminist theory as "doubly desiring" as places where women's meaning is not resolved ${ }^{2}$ and if this concept has a correspondence with the feral. Rereading Robinson in all these contexts liberates a radical potential for her work and moves critical attention beyond the recovery of eighteenth-century and Romantic women's writing and into a space where transgression and talent can be reoriented to be read as coevolutionary. For example, Robinson does not have to be read as a "Romantic writer" even as her historical moment and thick description can be read. Such a critical approach can counter the tranquillizing of the feral figure (in this case the eighteenth-century woman writer) whose perceived disruptiveness apparently necessitates imminent domestication (which could include canonization within Romanticism) or the designation of prey (the process of generating proof, for example, that the work of women writers does not 'measure-up').

In this way, leveraging Robinson's life and writing as feral ignites the practices of a feral ecocriticism which insists upon both historicizing representations of nature and revealing literature's and literary criticism's complicity in certain (mis)representations of nature (for example, romanticism's positioning of the 'savage') that fundamentally entrench, perpetuate and 'naturalize' human class positions and social roles, especially in their orientations to the natural world, by "romanticizing" them. In the context of Robinson’s work, I suggest provocatively that this is demonstrated through our reluctance to admit the feral position/perspective, our favoring of Romanticism as an aesthetic architecture despite the fact that it has aided in the institutionalization of oppressive social conditions through its aestheticization and idealized abjection of "the victim", an aestheticization which has its roots (at least) in the authorizing gesture of Romanticism towards affect (what we could also call, sensibility). Certainly this is the larger premise of Morton's text - that the reification of Romantic views of nature largely define nature in Western culture yet in the context of twenty-first century environmental degradation, do not seem to serve nature well at all. And I would add from an ecofeminist perspective that "the Romantic view" does not serve women well either. A feral ecocritical perspective refuses to merely report on Robinson's representations of nature, her roots in the Della Cruscan movement, her attraction to Gothicism, her highly developed sense of her own embodied celebrity nature. Rather this perspective exercises "lateral flows" and promotes Robinson and some of the marginalized figures she represents as viable catalysts and change-agents who problematize Romantic constructs and the implications of our inheritance of such constructs. Furthermore, I use Robinson to challenge feminist literary criticism to take notice of how its own tidy dramas of oppression-recognition, recovery, and canon reformation are only able to present a partial and limited account of women's varied literary histories. While undoubtedly Robinson's economic and health realities, her interpellation within celebrity culture, and her gender interfered with her ability to function legitimately within Romanticism, it may be to the point to suggest, in Timothy Morton's terms, that what evoking the feral activates is an inquiry into what Robinson offers in terms of ecology - a practice grounded in relations among living organisms in and of the environment - rather than in terms of nature: Robinson's individual presence as a physical and material phenomenon (see Morton 84). 


\section{Robinson's Thingness}

Part of this inquiry must be to extend the discussion from Mary Robinson as 'thing' to Mary Robinson as feral subject. When Anne K. Mellor begins her essay on Robinson with the question "Who - or what - was Mary Robinson?" and concludes that Robinson was "nothing more nor less than ... . a set of visual and verbal public texts" (Mellor 230, 256), she perceptively pinpoints Robinson's lengthy, intense and unusual objectification within patriarchy. Robinson began her parallel careers as actress and writer while still in her teens. Her first book of poetry was published and well-reviewed when she was about $17 .^{3}$ But her physical presence and celebrity intervened, and Robinson lived entirely in the public eye. Reportedly one of the most beautiful women in England, Robinson was literally an object of the public's gaze, hotly and continuously pursued by men including the Prince of Wales (with whom she had a year-long affair). In Robinson's case, she is sensationalized and affixed with a public nickname, "Perdita" (the lost one), regulated and judged in the public eye as either unredeemable or unlucky ${ }^{4}$. I suggest that she is neither and that she maintains an 'unfixed' quality which I call feral. Even Robinson's willingness to inhabit "Perdita" suggests her comfort with a feral identity. It is celebrity that contains and constrains her: as an actress and the lover of the Prince of Wales; she is both herself and someone else: and, in the context of Florizel and Perdita, a someone else who believes at times that she is one person when she is really another - a character who skillfully enacts several realities and identities in the course of one play.

In her analysis of the many Robinson portraits by painters such as Reynolds and Gainsborough, Mellor points to a variety of emphases from seductress to victim to whore. ${ }^{5}$ In her reading of Gainsborough's stunning 1781 full length portrait of Robinson, Mellor identifies details of bestiality and an unconstrained natural world by referring specifically to a "snaky vine coiling among the fig leaves" as a suggestion of Robinson's "uncivilized or immoral sexual desire” (Mellor 238). Though Mellor goes no further with her critical association of Robinson with a constrained nature and an unconstrained natural world, I would like to suggest that what is missing in this interpretation is a consideration of the radical potential of what Teresa de Lauretis discusses in relation to cinematic 'plot space'. For de Lauretis, while the "apparatus of looks converging on the female figure" in a plot space generate a fixed position for women, there is also potential for that female figure to "resist confinement in that symbolic space by disturbing it, perverting it, making trouble, seeking to exceed the boundary - visually as well as narratively . . . ” (de Lauretis 139).

There is evidence that Robinson herself was aware of both her need to express an affinity for nature and her understanding of herself, as a force of nature. When Mellor notes an association between melancholy and the sublime in the second Reynolds portrait from 1784, she finds a correspondence in Robinson's work. Synchronizing the second Reynolds portrait with Robinson's Memoirs moves the critical eye along a cohesive track where melancholy and sublimity mingle with and are coopted by pathetic fallacy to signal a seamless correspondence between woman and nature. The Memoirs generate a melancholic, transgressive-self/site that underpins Robinson's melancholy with legacy to construct an unstable self that Robinson parallels with her father's "tenacious", "ardent" and "hope[ful] character" (Memoirs I, 204). She pairs this 'nature' with a concern for her own legacy, offspring, literary legitimacy, and what can and cannot be said. She argues that her unaccountability lies in her melancholy nature which she 
reports began with her birth on 'a dark and stormy night': "I have often heard my mother say that a more stormy hour she never remembered. The wind whistled round the dark pinnacles of the Minster tower, and the rain beat in torrents against the casements of her chamber". This initial "tempest”, Robinson argues, "has followed my footsteps" (Memoirs I, 194). As if manufactured to explain (away) fissures in the sanctioned female person/persona, nature is drawn into service to account for complexity even as its own complexity is collapsed into trite and circular evocations which always seem to include storms, high winds, rough landscapes and deferred sunshine.

Such a gloomy disoriented selfhood, a negative feral caught between wild and domesticated, cannot help but falter, and it may be Robinson's introduction - the way in which she frames and represents herself throughout her life as of Nature in a very particular way - that dictates the failure of Robinson's story to cohere. The text's fractured nature, textual history, multiple authors and inconclusiveness speak to both the impossibility of autobiography and the limits hyperbolic evocations of nature place on the constructions of self both within and beyond language. The tempest she evokes becomes the thesis of her life, and she uses nature to shape and veil herself both for and from the public.

While the text functions at one level to sustain Robinson (psychologically and financially), to sustain her daughter, and ultimately ensure a future for her daughter (psychologically, financially and in terms of reputation), at another level, it creates, constructs and confuses her public, private, real, rendered, imagined, accountable and unaccountable selves. That she writes the Memoirs near the end of her life when she is suffering from the effects of poverty, illness, and drug dependency ${ }^{6}$ and does not enable the reader to account for that is another factor. Indeed, the fact that she does not allow the reader access to events beyond 1779 deepens her unaccountability. But her inaccessible celebrity founded largely on the shaky ground of Robinson's most transgressive public/private act -- her decision to engage in an adulterous relationship with the Prince of Wales -- utilizes what ecofeminist critic Catriona Sandilands calls an "ironic" politics, that "highlights the substantive emptiness of the very term that is being produced in articulation ... [and] inhabits an intentional space between the actual lives of women and the fantastic representations of the category [of woman] . . . in order to highlight its malaise” (see Sandilands 105-06). Robinson's transgression is all the more slippery because of this irony and the way in which it plays in her text with the questionable moral characters of the men involved with her to complicate any simple, single condemnation of Robinson herself. I view this as a positive sign that turns the text towards Robinson's powerful assertion of a writing self and a self-as-writer. Beauty, woman, celebrity, actress, self, writer, memoirist are all ironic terms that do political work in this text.

\section{Robinson's Thingness, The Memoirs, and their Continuation}

Both Robinson's physical beauty and the text of her life that she, Maria Elizabeth, and Pratt construct are feral spaces. Gendered feral, Robinson is not easily located on a continuum between male and female. She is ultrawoman, hyperfemale: she exists in an unaccountable space between public and private selves. Often the “object of attention” (Memoirs I, 207), Robinson's physicality overwhelms and directs the gaze - she becomes the unaccountable subject/object of the questions she first hears at age fifteen floating in the perfumed air at the Pantheon Concert: 
"who is she?", "who is that young lady in the pink dress trimmed with sable?" Even her answer to this apparently simple question is complicated in her account when the Earl of Northington thinks he knows her and asks if she is Miss Darby, not actually who she was before (Northington is an old friend of her father's), and fearful of the libertine manners of the men who desire to know "who she is", Robinson retreats conveniently to her recently domesticated and accountable self. ${ }^{7}$ She replies that her "name was now changed to that of Robinson: and, to prevent any awkward embarrassment, [she] presented [her] husband, on whose arm [she] was still leaning” (Memoirs I, 218).

In her Memoirs, she promotes her own "strong propensity to adore the sublime and beautiful of [God's] works" (Memoirs I, 142) even as she also documents the response that others, especially men, had to her physical presence. Despite the fact that many of these observations are accompanied by detailed self-descriptions of her careful attention to fashion, Robinson's discomfort and dis-ease with being always stared at fixedly, followed and questioned by strangers is palpable - especially in her first forays into London society as a teenage bride. ${ }^{8}$ She also allows her readers access to the moment at which she learned to accept, crave and be domesticated within that gaze. ${ }^{9}$ This moment took place during a stage performance in 1779 . She says, "I never shall forget the sensation which rushed through my bosom when I first looked towards the pit [and] I beheld a gradual ascent of heads. All eyes were fixed upon me” (Memoirs II, 3).

Robinson argues that as "an object of attention" she cannot largely account for herself because of the gap between what she experiences as an embodied self and what is projected on her. What Robinson both is able and unable to do in the Memoirs is to play in that gap, to confront her own nature -- her self-described melancholic character, her genius, her naivety, her passion, her intelligence and her uncanny beauty -- her "dangerous sort of portion” as Mr. Harris, her fatherin-law, describes it (Memoirs I, 215). ${ }^{10}$ I promote the feral not to deny that she is largely circumscribed and contained (both publicly and, in particular, privately) within ascendant male power and the limits of her social role but rather to suggest that there are other negative and positive externalities that the feral manifests and/or addresses that are textually available in Robinson's work but remain still substantially unread. ${ }^{11}$

Conscious of, haunted and inspired by the unaccountable feral spaces she finds herself in (her own body and face, London highlife, her marriage, the theatre, etc.), Robinson purposefully generates a memoir that in part accounts for her behavior and at another level acts as a feral intervention intended to confound and float her unaccountability over herself like the "pale blue lustring" she wears "so perfectly to [her] own satisfaction" on the day she is introduced to her future husband (Memoirs I, 208) or the "morning dishabillé of India muslin" she wears later in the narrative to confront her husband's mistress (Memoirs I, 223). Dressed in its guise as autobiography, the Memoirs seem at first glance to give the public the accountability it wants, or thinks it wants, from the story of her life and especially to account for the story of Robinson's affair with the Prince of Wales. But floating alongside this account lies what, in market-terms, Defoe critic Sandra Sherman might call the Memoirs' "epistemological opacity" where the text evades being "denominated a cheat, its author . . . a liar" by "deferring representational integrity." Such opacity, Sherman argues, allows "texts whose provenance is remote, whose authors are unaccountable ... [to] escape accountability” (Sherman 1-2). This epistemological 
opacity is aided by the text's production for a market that literally consumes celebrity and scandal -- and simultaneously desires and does not desire accountability from Robinson. Here a feral Robinson rides her own and the reader's delicate balance between truth and self-absorption to "play in the gap" as Sandilands would have it. And the gap Robinson plays in is also a textual gap. Only partially written by Robinson, The Memoirs supports and sustains the accountability that Robinson has already seeded in the content, and the text grows quickly out of the control of Robinson's daughter, Maria, and Pratt who Maria apparently contracts to finish her mother's Memoirs. What we find in the Continuation surprisingly, or perhaps not so surprisingly is that Robinson's ferality has generated a textual momentum, a trajectory that drives the text to make exactly the point that Robinson hoped to make: that she was fundamentally, fully, and finally a writer but also, fundamentally, unaccountable.

"Playing in the gap" between the Robinson-authored Memoirs and the Pratt/Maria Elizabethauthored Continuation further supports my contention that the Memoirs is a feral text. For Sandilands, playing in the gap "is not only about creating new ideas of women and nature ... but about active engagement with the old ones to disrupt notions of gender solidity, natural necessity, and reified identity in order to reveal their impossibility" (Sandilands 120). Robinson breaks-off the text at the moment in which she is delicately balanced between the wild and domestic of herself and the men with whom she is involved -- the "unbounded assurances of lasting affection” she receives from the Prince and the neglectful conduct of Mr. Robinson who "passed his leisure hours with the most abandoned women” (Memoirs I, 256). Throughout the text, Robinson laments her lack of a stable domestic life within her marriage and argues that her transgressions amount largely to her search for a 'real' husband. While she assumes the revelation of her longing will generate sympathy, she is also mapping a strategy. Robinson argues that she 'has to' transgress and enact wildness in order to find the domestic. She is also feral because she insists on writing and publishing all of this - not only as explanation for her behavior, but also to display that behavior. A more modest woman, for example, would have not transgressed in the first place but if she had, would have acknowledged her error of judgment and retired from public life. Even if the modest woman had determined to write her life, she would have certainly cast herself as a hapless victim in a much more abject and sentimental way than Robinson does here. Textually, the neglected wife is a feral springboard: abandoned, she behaves with abandon.

Both temporally and spatially, the gap between the Memoirs and the Continuation is a feral interval and a spatial divide. The traditional nodes of stability and abandon are reversed with the Prince represented as offering a kind of domestication Robinson says she craves and has been denied in her marriage by her husband's debauched lifestyle. Robinson also ferally straddles the gaps between financial independence and dependence. Ironically it is her public acting career that enables the Robinsons to 'domesticate': she supports the family. ${ }^{12}$ Furthermore, and like the blank page dividing the Memoirs from the Continuation, Robinson's potential capitulation to the "confidential Correspondence" of a relationship with the Prince of Wales brings her a brief sense of domestic peace, financial stability, and it enables her retirement from the stage. In the dynamic chaos of her 'circumstances', she goes feral: she simultaneously moves from the wild (libertine husband) towards the domesticated (well-kept mistress of the prince), from the domesticated (marriage) to the wild (adultery) meeting herself as and in the feral intersection of her own unaccountable lived experience. 
The very unfixed and ongoing movement of Robinson's story underlines a kind of truth-claim that seems not to have received much critical attention and speaks perhaps to the benign neglect of the role that aging has on textual production played out in the life of the writer. As another axis of feral intervention, Robinson's identity, so formed by her physical beauty and public presence, was realigned by a serious illness (likely rheumatism) which left her physically disabled and suffering from chronic pain for the rest of her life. When, therefore, in her Memoirs, Robinson laments her inability to form deep relationships, to find "a congenial spirit" in another human "abstracted from the world" (Memoirs I,142), her choice of feral human figures as poetic subjects becomes clearer. Notorious, thing-like, and disabled, Robinson seems to seek (and to some degree, find) what she calls "sacred intercourse" and "sublime union" the figures who populate "The Maniac" and "The Savage of Aveyron”, especially the latter.

Seeking "sublime union" is a different ambition than the move towards earthbound marriage and a fitting ambition for a woman and writer who according to literary critic Ashley J. Cross was interested in distinguishing herself and her approach to the 'problem' of the woman writer from the work of her friend, Mary Wollstonecraft, by asserting the essential role of passion in intelligent female discourse. In her 1799 essay A Letter to the Women of England, Robinson's 'politics of the poet' and her belief in the importance of public discourse for women writers direct her active intervention to elevate sensibility and philosophy into requisite strengths (Cross 54). But Jacqueline Labbe tempers Cross's enthusiasm by observing how Robinson struggles with sensibility as a force that stands in the way of her ability to write and even think clearly. Indeed, this inability to articulate her experience (both rational and emotional) may be what both draws Robinson to both "mad Jemmy" in "The Maniac" and the feral boy in "The Savage of Aveyron" and to a psychological manifestation of the feral and a feral poetics.

Her manic peppering of twenty-two questions in the 120 lines of "The Maniac" appears obsessive and intrusive as she tries to uncover a kind of truth behind the real-life incident that triggered the poem when Robinson witnessed 'mad Jemmy', a local "elderly man being hurried on by a crowd of people who pelted him with mud and stones" (Pascoe 122). When Patricia Meyer Spacks reads “The Maniac” as part of a series of poems in which Robinson "search[es] for emotional pretexts” (Spacks 252), she may be neglecting evidence of just how closely Robinson is able to identify with mad Jemmy. For example, Spacks points out that in line six, Robinson refers to Jemmy as a "THING FORLORN" and concludes that Robinson "briefly depriv[es Jemmy] of humanity ... [to exploit him as] an object for poetic speculation” (Spacks 253). But I would suggest that Robinson can identify a good deal with Jemmy's thingness and even with the experience of being "hurried on by a crowd of people who pelted him with mud and stones” (Pascoe 122). ${ }^{13}$ Spacks is right that at this level Robinson must successfully articulate her clear distance and distinction from "mad Jemmy". But she does this while displaying her sensibility, vulnerability and sense of identification with him. Prominent Robinson critic, Judith Pascoe points out that Robinson's account of the poem's composition “anticipates the composition story of Coleridge's 'Kubla Khan’” (122) and in this way implies an increasing cultural valorization of manic and inspired (whether substance-aided or not) creative practices. In this cultural context, it is important for us to read "The Maniac" critically if we are not to merely compound mad Jemmy's marginalization and 'thingness' by re-aestheticizing him and compounding our tendency to deny social justice to feral citizens. ${ }^{14}$ 
Part of the dynamic of this aestheticization has to do with literary criticism's attentiveness to form. In his work on eighteenth-century madness and writing, Allan Ingram illuminates how a recovered mentally-ill author's desire to generate an accurate portrait of his mental condition at the time of his illness is usurped by his greater need to write well. ${ }^{15}$ This writing-well often manifests itself formally and in "The Maniac”, Robinson, under the influence of a large dose of laudanum, manages to adhere to strict formal, metrical, and rhythmic order as if by pulling the form of the poem together, the content adheres as well. ${ }^{16} \mathrm{I}$ believe that this is why critics have tended to dismiss the actual content of the poem in favor of the more sensational composition story. But what is revealed through a close reading is Robinson's liberal understanding of Jemmy's madness as a social phenomenon and of poetic form itself as a social phenomenon. While Robinson ultimately offers him only "soft Pity" (120), she variously speculates on the causes of his madness. Some of her imagined causes are clearly socially determined: greed, ambition, poverty, and guilt. All are deeply emotional including Jemmy's possible experience of failed love or friendship, jealousy, and ingratitude.

Robinson's speculations and approach fail Jemmy by denying him space to speak, but her desperate need to understand him are signaled formally by the use of upper case exclamatory words, phrases, and labels. At the beginning of the poem, she performs a kind of anti-blazon on Jemmy moving from his "matted hair" (7) to his "burning bosom bare” (8), "lip . . parch’d”, "groan so deep” (9), "ghastly smile” (15), "pale distorted face” (16), and "scowling brow” (26) but stops when she meets his eyes:

Fix not thy steadfast gaze on me, SHRUNK ATOM OF MORTALITY!

Nor freeze my blood with thy distracted groan;

Ah! Quickly turn those eyes away, They fill my soul with dire dismay!

For dead and dark they seem, and almost chill'd to STONE! (43-48).

Robinson's reluctance to really engage with Jemmy displays her own fear of crossing from marginal to madness. It relates to Jemmy's age and Robinson's perception of the level at which he is entrenched as marginal and excluded from the ethic of care within the community. This potential attentiveness to an ethic of care also signals a feminist path through this challenge that acknowledges how "discourse ... far exceeds philosophy's power of codification” (Braidotti 5) and "epistemophilic drive [that encompasses] a will-to-know that is fundamentally affective" (Braidotti 6). Braidotti's emphasis on the body as "our primary situation" also underlines what Adrienne Rich has called "the politics of location", a situated agency which "functions as a strategy of resistance” (Braidotti, "Embodiment" 8) - a companion concept for the rereading of 'plot space' illuminated earlier in connection with the Robinson portraits and caricatures.

“The Savage of Aveyron” presents a slightly different situation to that of "The Maniac". Here the feral extends to Robinson's poetics where as Pascoe points out, "Robinson internalized the idiosyncratic meter of Coleridge’s incantatory poem ['Kubla Khan']” (58). As Pascoe illuminates, Robinson's "replication of Coleridge’s mazy measure and fraught tone ... shows Robinson’s studied craftsmanship and persistent emotional intensity” (Pascoe 59). But Pascoe 
tends to dismiss the content of the poem relegating it to "focal points of popular culture [which Robinson turns] to literary advantage” (20). Again, I would argue that while Pascoe's reading helps with the feminist project of affirming and canonizing women writers of the period, it neglects to read Robinson's deeper sense of concern for herself in the feral and her eighteenthcentury engagement with the occasional and material worlds.

In "The Maniac", Robinson distances her speaker from mad Jemmy by excising the event that triggered the poem and by setting the poem chronologically, after the fact. "The Maniac" becomes a site of inquiry in which Robinson and Jemmy (despite her search for "sacred intercourse" and "sublime union") remain alienated. In "The Savage of Aveyron", on the other hand, Robinson creates a more dynamic scenario in which the speaker populates the "lonely wood of Aveyron" (2) and actually comes into contact with the feral boy. Robinson populates the natural world with feminine gothic tropes such as a "torrent" (5), "thorny alleys" (11), a "winding path" (and "pale moon" (15). Her explanation for a root cause of the boy's ferality involves a standardized story of implied rape and murder of the boy's mother at the hands of ruffians likely intended to account for the incomprehensible cultural idea of child-abandonment by a mother. The story is enriched with the natural/unnatural sign of the "sapless" (158) oakand the affinity of nature which "mark[s] the spot where MURDER foul was done" (159). Robinson identifies with the boy directly by referring repeatedly to her "I" speaker as alone and worldweary. The speaker's curiosity about the cries she hears as she walks through the woods seem calculated to intensify their connection and even merge the speaker and the boy in that hoped for sublime union. The feral boy speaks and gestures his sense of alienation and loneliness using his only word, “Alone”, a word taught to him by his dying mother (see lines 160-3) and Robinson intertwines the speaker's repeated yearning to be "a traveller alone” $(27,39,51,63,87)$ with the boy's cries. She neither pities the boy, drives him away as she does in "The Maniac", nor offers to redeem him. He is accepted as inherently feral, and the speaker is left at the end of the poem to reflect that she "thought [her]self alone" but must now wonder whether she or he "could a wretch more wretched be,/More wild, or fancy-fraught than he/Whose melancholy tale would pierce AN HEART OF STONE.” (171-4). The distancing of the two poems is distinguished by these common references to STONE - Jemmy's near-stone eyes and the feral boy's story which- as if "mad Jemmy's" entrenched marginality is beyond identification while it can be comprehended in the feral boy. Typically, interest in feral children focuses entirely on their potential for recuperation (see Benzaquén). Robinson seems willing to let the boy be and accepts the naturalness of his state. Clearly implicit in this is an ethic of care with respect to the relationships between mothers and children, but Robinson's poem avoids both the didacticism of contemporary conduct manuals in proscribing this care as duty and the conventionalized middleclass stance of female benevolence.

A feral poem in some respects, Robinson's writing of the boy's story appeals only to the reader's reception. The difficult work comes with what happens next. How we perform out of our readings of the feral as feral readers is a significant part of this process and links literature to the politics of, for example, Nicholas Garside’s “feral citizen” who responds to the need to revitalize the disruptive, critical and exploratory nature of a genuine commitment to democracy. Garside's call for a "consciously feral method" (142) can be repurposed for feminist literary studies to move feral readers beyond a consideration of how individual eighteenth-century women writers succeed or fail as competent Romantics and onto more fundamental issues - social, 
environmental and political issues, issues of democracy relevant to both the eighteenth and twenty-first centuries as well as issues related to poetics and the actual content of women writers' textual productions.

With The Memoirs and these poems, Robinson writes herself into a new truth about women writers that makes recovering Robinson not nearly enough. While respectful treatments of Robinson always separate her celebrity from her writing, they are not separate. Her celebrity is not merely grounded in her thingness: it is grounded in her writing. No mere poetaster, Robinson really 'plays in the gap'. She expertly leverages her looks - the thingness both culture and politics understand about women - to negotiate her life and her story on her own terms. We are not reading well if we fail to recognize this and flatten Robinson's ferality with a banal explanation of how she is crushed and circumscribed by patriarchy. By writing well, by thinking well, Robinson took on and played out her multiple roles, doubly desiring an extended and extensive plot space - “disturbing ... . perverting . . ., making trouble, seeking to exceed the boundary” (de Lauretis 139), ferally elusive, engaging, and potentially inviting. By reading Robinson both in the context of the feral and with a feral critical openness, feminist literary studies in the twenty-first century can benefit too by entertaining a feral openness, by 'playing in the gap'. 


\section{Notes}

1. Paula Byrne casually assumes the continuation is by Maria Elizabeth and even accuses Maria Elizabeth of falsely representing the date of Robinson's birth as 1758 (see Byrne 243, 251, 400). Hester Davenport asserts that it was likely Pratt who helped Maria with the Continuation. Davenport quotes a letter from Maria to William Godwin in which she refers to herself as an "accessory" to the biographer and suggests that it "is likely that she and her accomplice concocted a plan to pretend that Mrs. Robinson had broken off her writing, to select from what came later and present it impersonally" (75). Linda H. Peterson underlines the importance of Robinson's Memoirs as "a historically pivotal and generically significant text” (36).

2. I mean resolved along an Oedipal trajectory: the term "double desiring” is a feminist response to psychoanalytic theory. See, for example, de Lauretis and Braidotti.

3. Robinson published prolifically throughout her life including five collections of poetry, four novels, two political treatises, many essays and uncollected poems (see Pascoe 19, 392-423).

4. The name comes from Shakespeare's The Winter's Tale. As an infant, Perdita, the daughter of Leontes and Hermione is sent to her death, but a sympathetic servant releases her into the wild. She is adopted by a shepherd but eventually learns that she is a princess, and she returns to the kingdom. Robinson famously played the role of Perdita in an adaptation of the play, entitled Perdita and Florizel. It was while playing this role that the Prince of Wales fell in love with her, and he apparently signed his letters to her with the name "Florizel". The pair was continually referred to in the press as "Perdita and Florizel”.

5. Other well-known portraits of Robinson are by George Romney and Angelica Kauffman.

6. In 1783, Robinson became seriously ill and suffered paralysis of her lower limbs (see Memoirs note 34, 384).

7. It is probably worth noting that Thomas Robinson "suggested the necessity of keeping our union a secret” (Memoirs 209).

8. Mary Darby was married to Thomas Robinson when she was 15, but he proved to be unfaithful and impecunious.

9. Robinson was never able to seek protection and traditional domestication from her debauched husband. Indeed, she supported him financially by renewing her acting career and writing for money. She was also drawn into adultery and secured several annuities (including one from the Prince of Wales) in this way, but she was never willing to completely abandon propriety. 
10. Prior to meeting Mary Darby Robinson for the first time, her future father-in-law, Mr. Harris says to Mr. Robinson, "I hope she is not handsome, . . . [for] beauty, without money, is but a dangerous sort of portion" (Memoirs 215).

11. For example, on 279 of the Continuation, she reports that while ill she is "prohibited by her physician ... from [writing poetry and even] thinking” (Memoirs).

12. Robinson's income from acting allows the Robinsons to resume a normal London routine after nine months jailed in the house of a sheriff's officer for Thomas Robinson's nonpayment of debts. John Fyvie disputes claims that Robinson turned to the stage to keep her husband out of debtor's prison and asserts that Robinson deliberately put herself on display (Bolton 735).

13. Clearly the story of the composition of “The Maniac" is a performance of sorts publicized by Robinson's daughter to show-off the poem's composition as an "affecting performance, produced in circumstances so singular, [that it] does no less credit to the genius than to the heart of the author" (Memoirs II, 132). Another motivating factor for Robinson was that she also needed to make money. According to Judith Pascoe, Robinson was "in a state of near constant financial desperation" and was arrested for debt several times, including in 1800 (the year of her death) for a $£ 67$ debt (33). As a woman she also needed to publicly demonstrate her intelligent rationality in order to be taken seriously as a writer. Further, Robinson had to show that she was a 'real' woman by overtly practicing and promoting benevolence.

14. For example, a number of social critics who have studied the 'feral child' phenomenon conclude that most of these children were not kidnapped by bears or wolves but had run away from abusive families. For example Adriana S. Benzaquén asserts that Peter of Hanover (a famous feral man captured in Germany in 1725) was the mentally challenged son of a local man who had physically abused him (92-3). With regard to this same case, I have also pointed out elsewhere the flaws in the local ethic of care by which a community would allow a child to disappear in the first place "and make it possible for him to be found years later by villagers who ... had no idea who he was” (Milne 339).

15. Patricia Meyer Spacks also compares Robinson to William Cowper whose struggles with mental illness occasionally manifest in his technique of seeming "to talk to himself" which for Spacks "contributes to the immediacy and energy that one feels in his verse" (262). Spacks does suggest though that of the two, Robinson is much more prone to "claim intense emotion” and credits Cowper with preserving "a dignity of reticence" (264).

16. Though I am not suggesting that Robinson was mentally ill, the fact that she was heavily dosed with laudanum when she wrote the poem and that this substance use-composition was publicized as evidence of her genius is significant in the context of her attentiveness to form. Formally, "The Maniac" consists of 6-line "women's" or "Spanish Sestet (Sexilla)” stanzas, iambic tetrameter meter with a rhyme scheme of aabccb. 
Works Cited

Alcoff, Linda Martin. "Mignolo's Epistemology of Coloniality”. CR: The New Centennial Review 7.3 (2007): 79-101. Print. http://dx.doi.org/10.1353/ncr.0.0008

Benzaquén, Adriana S. Encounters with Wild Children: Temptation and Disappointment in the Study of Human Nature. Montréal: McGill-Queen’s UP, 2006. Print.

Bolton, Betsy. "Romancing the Stone: 'Perdita' Robinson in Wordsworth's London.” ELH 64.3 (1997): 727-59. Print. http://dx.doi.org/10.1353/elh.1997.0022

Braidotti, Rosi. "Embodiment, Sexual Difference, and the Nomadic Subject," Hypatia 8.1 (1993): 1-13. Print. http://dx.doi.org/10.1111/j.1527-2001.1993.tb00625.x

Byrne, Paula. Perdita: The Literary, Theatrical, Scandalous Life of Mary Robinson. New York: Random House, 2004. Print.

Cross, Ashley J. "He-She Philosophers and Other Literary Bugbears: Mary Robinson's A Letter to the Women of England". Women's Writing. 9:1 (2002), 53-68. Print. http://dx.doi.org/10.1080/09699080200200153

Davenport, Hester. The Prince's Mistress: A Life of Mary Robinson. Gloucestershire: Sutton, 2004. Print.

de Lauretis, Teresa. Alice Doesn't: Feminism, Semiotics, Cinema. Bloomington: Indiana UP, 1984. Print.

"Feral.” OED Online. June 2011. Oxford English Dictionary. Web. 6 July 2011.

Garside, Nicholas. Feral Citizens, Democratic Ideals and the Politicization of Nature. Unpublished Dissertation. North York: York U, 2006. Print.

Ingram, Allan with Michelle Faubert. Cultural Constructions of Madness in Eighteenth-Century Writing: Representing the Insane. Basingstoke: Palgrave Macmillan, 2005. Print.

Labbe, Jacqueline. "Communities: Mary Robinson, Charlotte Smith, Anna Laetitia Barbauld, and Romanticism." Literature Compass. 1.1 (2004): 1-12. Print. http://dx.doi.org/10.1111/j.1741-4113.2004.00093.x

Mellor, Anne K. "Mary Robinson and the Scripts of Female Sexuality.” Representations of the Self from the Renaissance to Romanticism. Eds. Patrick Coleman, Jayne Lewis, and Jill Kowalik. Cambridge: Cambridge UP, 2000: 230-259. Print.

Mignolo, Walter D. Local Histories/Global Designs: Coloniality, Subaltern Knowledges, and Border Thinking. Princeton: Princeton UP, 2000. Print. 
Milne, Anne. "Fully Motile and AWAITING FURTHER INSTRUCTIONS': Thinking the Feral into Bioregionalism." The Bioregional Imagination: Literature, Ecology, and Place. Eds. Tom Lynch, Cheryll Glotfelty, and Karla Armbruster. , Athens: U of Georgia P, 2012. 329-344. Print.

Morton, Timothy. Ecology without Nature: Rethinking Environmental Aesthetics. Cambridge: Harvard UP, 2007. Print.

Pascoe, Judith, ed. Mary Robinson: Selected Poems. Peterborough, Ontario: Broadview, 2000. Print.

Peterson, Linda H. "Becoming an Author: Mary Robinson's Memoirs and the Origins of the Woman Artist's Autobiography.” Re-Visioning Romanticism: British Women Writers, 1776-1837. Ed. Carol Shiner Wilson and Joel Haefner. Philadelphia: U of Pennsylvania P, 1994. 36-56. Print.

Robinson, Mary. “The Maniac.” Poems. London, 1793. Print.

---. Memoirs of the Late Mrs. Robinson Written by Herself. 2 vols. London, 1803. Print.

---. "The Savage of Aveyron.” The Poetical Works of the Late Mrs. Mary Robinson: Including Many Pieces Never before Published. Vol. 2. London, 1806. Print.

Sandilands, Catriona. The Good-Natured Feminist: Ecofeminism and the Quest for Democracy. Minneapolis: U of Minnesota P, 1999. Print.

Sherman, Sandra. Finance and Fictionality in the Early Eighteenth Century: Accounting for Defoe. Cambridge: Cambridge UP, 1996. Print. http://dx.doi.org/10.1017/CBO9780511582219

Spacks, Patricia Meyer. Reading Eighteenth-Century Poetry. Chichester, West Sussex: WileyBlackwell, 2009. Print. 